\title{
A Historical Analysis of Human Rights And Women's Status in Pakistan
}

\author{
Abida Parveen \\ Sheikh Zayed Islamic Centre \\ University of Karachi
}

\begin{abstract}
Human rights are the fundamental rights which are inherent to all human beings. Whatever the nationality, place of birth, caste, gender, ethnic or national origin, religion are equally entitled to human rights without discrimination. All these rights are interconnected. These rights are resulted by the struggle of different human societies. In 2003 Byrne Darren stated that "the in alienable and indivisible right held by all are the basic standards of justice. Without justice and equality people cannot live with dignity. Human rights are a set of individual and collective rights that have been formally promoted and protected by international and domestic law since the UN Declaration of human rights in 1948. Islam gave human rights as early as the fourteenth century. In Islam one tries to remain subservient in total submission to the creator, the ever living one true God (Allah). The true guidance in life can only come from Holy Qur'an and the Qur'an has the answers to change the tears of the world into smiles. In the Qur'an women is raised to a status of a dignified human being.
\end{abstract}

Keywords: Human Rights, Women's Status, Domestic Law, Justice, Equality

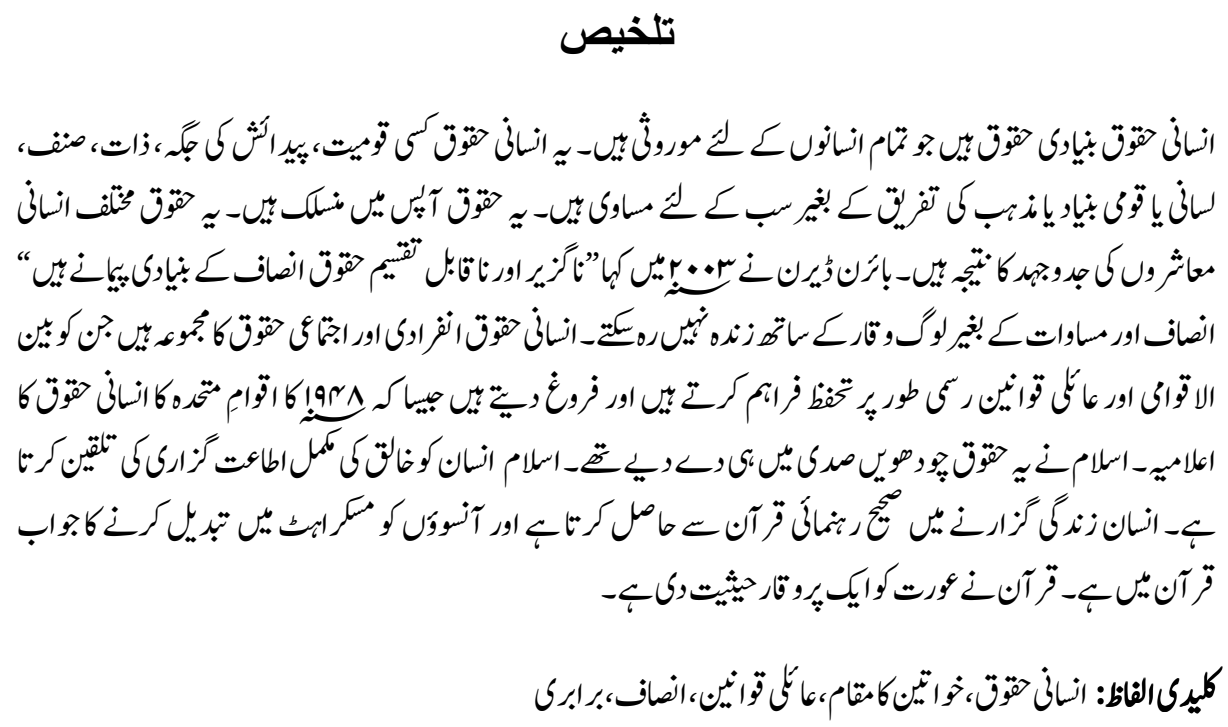

\section{Introduction}

Human rights may be regarded as those fundamental rights in any part of the world is entitled by virtue of having been born as human being. In common parlance these rights may be said those rights which are inherent in the people by virtue of their being human being. 
Human rights are guaranteed by law in the forms of treaties, customary international law, general principles and other sources of international level. Human rights law are obligations of governments to comply in certain ways or to refrain certain acts in order to promote and protect freedom of individual or groups. According to Hannum, "The fundamental rights that humans have by the fact of being human, and that are neither created nor can be abrogated by any government" (Hannum, 2011). Blattberg (2009) described that human rights are "Commonly understood as inalienable fundamental rights to which person is inherently entitled simply because she or he is human being". Human rights are thus conceived as universal and egalitarian. That mean these are applicable everywhere and equally for everyone. "These rights may exist natural rights or as legal rights, in local, regional, national and international law".

Human Rights are about human both in individual and collective sense. Anybody has the right to argue as human being what he or she has the rights? These are accepted standards of permitted and forbidden actions in a state, which are consonant with justice, reason or goodness. These standards are maintainable morally and socially and can be justifiably claimed by anybody (Littman, 2003). The rights refer to those rights that are universal to humanity based on justice, regardless of residency status, ethnicity, citizenship and gender. The term "first gained wide usage in English due to the abolitionist movement, which drew on the common humanity of slaves and free persons" (Alston, 1992). According to the article 18 of Universal Declaration of Human Rights "when someone wants to speak about human rights, requires a conception of what rights one possesses by virtue of being human. That does not mean human rights in the self evident sense that those who have them, but rather, the rights that human beings have simply because they are human beings and independent of their varying social circumstances and degrees of merit (Donnley, 1989).

In the human history of civilization, the idea of rights and liberty existed although theme were different conception as in modern time. The famous experts on human rights Jack Donnelly described of that in the traditional societies the systems of "duties conceptions of justice, political legitimacy and human flourishing that sought to realize human dignity, flourishing, or well being entirely independent of human rights. These institutions and practices are after native to, rather than different formulations of human rights" (Donnley, 1989). The modern sense of human rights can be seen from the Renaissance Europe and the Protestant Reformation. These were developed during the early modern period alongside the European secularization of Judeo Christian ethics. The concept of human rights evolved in the west as important ethical concepts of justice and equality. McIntyre believed that there was no word for "right" in any language before 1400. Medieval charters of liberty such as the English Magna Carta were not charters of human rights, rather these were the foundation of limited and agreement to address 
specific political circumstance, in the case of Magna Carta later being recognized in the course of modern discussion about rights (Blattberg, 2009)

\section{Islamic View of Human Rights}

Prophet Muhammad (Peace be Upon Him), fourteen hundred years before gave a complete packages of human rights in the farewell sermon. He presented such guiding principles for protection of human rights, which when applied, have the potential of creating peace to the suffering people of entire planet. The Prophet said about human beings:

O people listen carefully to what I say! May be the next year after this (Pilgrimage) I never meet you again.

O People. God has created you from only one man and a woman and distributed you in groups and tribes, so that you could be recognized distinctly; To Allah, he / she from among you is more respected and eminent, who is the more pious among you.

O people listen carefully; your sustainer is one and your father is also one. Remember, neither a nun-Arab has superiority over an Arab, nor an Arab a non-Arab; neither a black man has preference over a white one, nor a white man over a black one.

All human beings are the opposing of Adam and there is no reality about Adam except he fact that Adam was created out of clay (Khan, 2008).

The Prophet (Peace be Upon Him) said:

Now, all claims of superiority and nobility, all demands of blood and wealth, all retribution stand crushed under my feet. However, guardianship of the House of Allah and services of providing drinking water to the pilgrimage performance will continue unchanged (Khan, 2008).

This enunciates universal fraternity. The last sermon of the Prophet Muhammad (Peace be upon him) eliminates tribal and regional prejudices. It establishes universal brotherhood, put an end to tribal vendettas and revenge killings and put an end to tribal vendettas and revenge killings. It also, provides the basis of a just economic system. 
Prophet Muhammad (Peace be Upon Him) protected of rights of women and ensured:

O' people! Your women have got rights over you. Similarly, your rights are upon your women. One of these rights is not to let any man others than her husband to establish sexual relations with her. Women should absolutely keep away from committing perversion. Should they happen to commit this mistake. Their husbands are allowed to punish them, but it should not be excessive (Sani, 1999).

He stressed that

Among the rights that women have upon you, one is that you should feed and clothe them well. I advise you to behave fairly with women because, on entering the wedding contract with you, they become submissive to you and do not remain independent. Fear Allah in their case. As you obtained them in the name of Allah on his name alone, they became legitimate to you (Sani, 1999).

The Quran is thus, provides the basis and guidelines for the protection of women rights. This sermon is the final guidance of the Holy Prophet to the community.

This remarkable farewell message is a charter of emancipation for all oppressed people and the basis for a just socio-political system. This sermon bears good findings for all humanity. The practical application in true spirit will serve the safeguarding of the rights of all people on earth. It is the best contribution of Islam to world civilization.

Prophet Muhammad (Peace be Upon Him) practiced each and every command laid down by the Quran and set up an ideal society on this basis. His deeds are recorded in compilation known as Sunnah. Under the social system of Islam, no human being is discriminated on ground of gender, power or wealth. We find many verses in the Quran which clarify the position of man and woman in society. Both are like two wheals of a carriage jointly working for its smooth running. Both are equally important in the eyes of God. The status of women in Islam will be discussed again in this article.

Here, we have to examine the state of Human Rights from $18^{\text {th }}$ to $20^{\text {th }}$ century with reference to the charter of United Nations.

\section{Human Rights in Various Centuries}

The issue of the Human Rights was introduced by Spanish clarics, such as Francisco de Vitoria and Bartolome de Las Casas. In the Valladolid, Juan Gones de Sepulvede, 
mentioned an Aristotelian view of humanity as divided into classes of different worth, argued with Las cases who argued in favour of equal rights to freedom of slavery for all human regardless of race of religion (Hannum, 2011). In Britain in 1683, the English Bill of Rights, an Act Declaring the Rights and Liberties of the subject and setting the succession of the crown and the Scottish claim of Right each made illegal a range of oppressive governmental action (Blattberg, 2009).

In United States, major charges emerged during the $18^{\text {th }}$ century (1776) leading to the adoption of the United States Declaration of Independence. In France the French Declaration of Rights of Man and of the Citizen was established. Both of these provided certain legal rights. These were followed by the Virginia Declaration of Rights in 1776 emerging a number of fundamental civil rights and freedoms. These all hold that all men are created equal and endowed by their creator with certain unalienable rights that among these are life, liberty and the pursuit of happiness (Blattberg, 2009).

These were followed by philosophers such as John Stuart Mill, Thomas Paine and G.W.F Hegel during $18^{\text {th }}$ and $19^{\text {th }}$ centuries. The term human rights in Europe and USA was used in Paine's the Right of Man and William Lloyd Garrison's in 1831 writings in the Liberator. He mentioned that the way trying to enlist his readers in "The Great Cause of Human Rights". Blattberg also said that the term "Human Rights" has been used by one author in 1742 (Blattberg, 2009).

During the early $19^{\text {th }}$ century, William Wilberforce in Britain worked for the abolition of slavery and because of his efforts the British crown passed the Slavery Abolition Act in 1833. The institution of Slavery had abolished between 1778 and 1804 in the Northern States of the USA. This "Peculiar institution" resulted the civil war in America in Southern states. Soon, after several amendments to the constitution of the USA were made (Hannum, 2011). The thirteen amendment banned slavery and fourteen amendment gave full citizenship and civil rights to all people born in the USA and the $15^{\text {th }}$ amendment guaranteed African Americans the right to vote (Hannum, 2011).

During the $20^{\text {th }}$ century, many movements were launched to achieve human rights. In the west (Europe / North America) professional social groups (labour unions) brought about laws granting workers the right to strike, work hours and forbidding child labour. The movements were also successful to achieve right of vote for women. National liberation movements succeeded in driving out colonial powers. The Indian subcontinent was divided into two parts and ended the British Raj. Movements by long oppressed racial and religious minorities had been successful in various parts of the world i.e. the African American civil Rights movements, minorities Movements and Women Movements in the USA. In 1864 the Red Cross, the labour code and the Geneva Convention were established. This laid the foundation of International Humanitarian Law, which further 
developed following the two World Wars (Hannum, 2011). The League of Nations was established in 1919 and the Treaty of Versailles helped to end the war. The League's goals included disarmament collective security, improving global welfare and settlement of disputes between countries through negotiation.

In fact, the charter of the League of Nations was a mandate to promote human rights which were later incorporated in the Universal Declaration of Human Rights. After the world war II, the Yalta conference (1945) the Allied Power established, The United Nations. The United Nations played important role in developing human rights and international human rights through its forum International Humanitarian Laws and International Human Rights Law were agreed. The United Nations charter provided a basis for the development of international rights protection. The preamble of the charter provides that the members "reaffirm faith in fundamental human rights in the equal rights of men and women" (Johnson et.al., 1998). It states that the purpose of the formation of the United Nations is "to achieve international co-operation in solving international problems of an economic, social, cultural or humanitarian character, and in promoting and encouraging respect for human rights and for fundamental freedom for all without distinction as to race, sex, language and religion" (Charter of the United Nations).

\section{Discussion}

Today there are numerous international treaties on human rights promulgated since the UN Declaration to which increasingly large number of Nations States are a party, while the language of human rights increasingly pervades moral, political and legal vocabulary to such an extent that may have claimed we now live in an age of rights. Human rights are those fundamental rights to which every man and or women living any part of the world entitled by virtue of having been as human being.

There are two main approaches of human rights, first is the Western and second is the Islamic approach. Mostly in Western societies, it is believed that the world has got the concept of human rights from the west. Western thinkers and scholars say the world has got the modern human rights from the great charter of Magna Carta, the first document received by the king from his subjects, which was issued by King John in 1215, but it did not limit the power of King in middle ages and it was just a piece of paper. Until $17^{\text {th }}$ century, Elizabeth and Stuart periods no one knows that Magna Carta contained the principles to bound the king to renounce certain rights, respect legal principles, respect procedure control of parliament on the right of taxation and accept that the will of king could be bound by law. It shows that Western nations had no concept of human rights till the end of $16^{\text {th }}$ century. We find explanation of these concepts or ideas at the end of $18^{\text {th }}$ century in the constitution of USA and France. After the USA and French constitutions many other countries included basic human rights in their constitutions but were not given 
to their people in their reality. In the middle of $20^{\text {th }}$ century the United Nations passed the Universal Declaration of Human Rights against genocide and therefore, formulated the laws to check and revise it. Under the United Nations charter, an intergovernmental body seeks to apply international jurisdiction for universal human rights legislation. Within the UN machinery, human rights issues are primarily the concern of the United Nations Security Council and the United Nations Human Rights Council and there are numerous committees for safeguarding different human rights treaties (Safdar, 2005). The United Nations has an international mandate to achieve international cooperation in solving international problems and disputes of an economic, social, cultural or humanitarian character, and in promoting and encouraging respect of human rights and for basic freedoms for all without distinction of race, language, religion or gender (Henkin, 1987).

Islam is Universal religion which introduced the concept of human rights before any other society in the world. Islam gives the ideas of a noble individual regardless of his/her caste, colour and creed and restored the dignity of entire humanity. Islam paved a way for an integral forum of existence for all human beings, dignity of man and woman in the society in terms of security and sanctity. When we talk about human rights in Islam mean the rights which are directly granted and gifted by God. These rights are not granted by any legislative council. In Islam, all the rights are given to man and women by God. No legislative assembly or government has the authority to abrogate or withdraw them. These rights are the part of the Islamic faith. As Islam is a universal religion and the human rights are not only for its followers but they are for all mankind as human being. According to Islamic human rights philosophy all the human beings are endowed by their creator with certain basic rights regardless of birth, place, caste, colour or gender.

\section{Status of Women in Islam}

Islam has guaranteed and safeguards right of women and has enjoined upon the entire society to treat women with respect, kindness and consideration. After Allah (God) and the Prophet (Peace be Upon Him) the highest status is given to mother. A respectable treatment of both parents has been enjoined and made mandatory. The Quran says:

And We have enjoined on man (to be dutiful and good) to his parents. His mother bore him in weakness and hardship upon weakness and hardship, and his weaning is in two years give thanks to me and to your parents, unto $\mathrm{Me}$ is the final destination (Al-Qur'an, 31:14).

Prophet Muhammad (Peace be Upon Him) asked his companions emphasized very good treatment of the mother. The role of women in Islam is of a wife. Women has a distinct figure which does not merge with personality of her husband after marriage, nor a woman her husband's slave. Marriage entails assumption of some new responsibilities. Her rights 
too cannot be usurped. The marital relationship is one of mutual love and devotion. Islam has bound man not only to fulfil the legal rights of his wife, but also to treat her with love. Sometime a husband does not love his wife because of some fault in her. It is but natural. In such cases too, man is duty bound to treat her well because even her faults might be a hidden blessing for him. The Quran says:

O you who believe! You are forbidden to inherit women against their will, and you should not treat them with harshness, that you may take away part of the Mahr you have given them, unless they commit open illegal sexual intercourse. And live with them honourably. If you dislike them, it may be that you dislike a thing and Allah brings through it a great deal of good (Al-Qur'an, 4:19).

The Quran stresses:

And among His Signs is this, that He created for you wives from among yourselves, that you may find repose in them, and He has put between you affection and mercy. Verily, in that are indeed signs for a people who reflect (Al-Qur'an, 30:21).

In Islam, a wife has been said to be the best of worldly goods. If a woman as wife is granted due status in the family, it would certainly result in the emergence of ideal family and consequently, of an ideal society.

The status of a daughter in Islam is also very important. Islam preached that daughter should be cherished and loved. How a daughter was treated in pre Islamic society, the Quran mentioned:

And when the news of (the birth of) a female (child) is brought to any of them, his face becomes dark, and he is filled with inward grief!

He hides himself from the people because of the evil of that whereof he has been informed. Shall he keep her with dishonour or bury her in the earth? Certainly, evil is their decision (Al-Qur'an, 16:58-59).

Islam has given full legal rights and privileges to women and at the same time she is morally an object of respect and esteem. Islam stresses that a woman's chastity has to be respected and protected under all circumstances, whether she belongs to our own nation or to the nation of enemy, whether she is our co religion or belongs to any others religion. The Quran says:

“Do not approach adultery" (Al-Qur'an, 17:32). 
Islam prescribed very hard punishments for chastity. Anybody violating the chastity of woman, cannot escape from punishment. This right of chastity of woman has been gifted by God.

Islam recognizes equality for all human race regardless of colour, gender, race, language or nationality. According to Islamic Human Rights all human being are equal. The Qur'an says:

O mankind! We have created you from a male and a female, and made you into nations and tribes, that you may know one another. Verily, the most honourable of you with Allah is that (believer) who has At-Taqwa [i.e. one of the Muttaqun (pious - see V.2:2)]. Verily, Allah is AllKnowing, All-Aware (Al-Qur'an, 49:13).

Thus, it can be said that goodness and virtue is in all cases better than vice and evil. Islam laid down the principles that no citizen can be imprisoned unless his/ her guilt has been proved in an open court and to arrest anybody on the basis of suspicion and throw him into prison without proper court proceedings and providing him a reasonable opportunity to produce his/ her defense is not permissible. The Qur' an says:

Whenever you judge between people you should judge with the sense of justice (Al-Qur'an, 4:58).

In Islam all the people have the right to freely express their ideas and feelings on the condition that it could be used to spread the virtue and truth and not for spreading evils. No one has the right to use offensive language in the name of criticism. The Qur' an says:

They enjoins what is proper and forbid what is improper (Al-Qur'an, 9:71).

In Islam, freedom of expression is not only a right but it is also an obligation of calling people towards the right way and forbidding them from evils. The government has the duty to promote the freedom of expression for the propagation of virtue and truth.

In Islam, everybody has the basic fundamental right to freedom of faith and belief. It stresses that all are equal in the eyes of law, even the rulers are not above the law. No one is above the law and cannot claim immunity. The Quran and the Sunnah are the basis of Islam and are the guiding light in all aspect of human life, social, political, moral, spiritual and women rights. The Qur' an says:

It is he who created you from a single person, and made his mate of like nature, in order, that he might Burden and caries it about (Unnoticed), when she grows Heavy, they both pray to God (AlQur'an, 7:189). 
These words clearly describes that both men and women are created from a single "person" as each other companions or places of rest.

God created all living being in pairs, male and female but no means one superior to other. The Qur'an says:

And God has made you mates (and companions) of your own nature, and made for you, out of them, sons and daughters and grandchildren, and provided for you sustenance of the best; will they then believe in vain things, and be ungrateful for God's favours? (Al-Qur'an, 16:72).

The Qur'an says:

For Muslim men and women, for believing men and women, for devout men and women, for true men and women. For men and women who are patient and constant, for men and women who give in charity, for men and women who fast, for men and women who guard their chastity and for men and women, who, engage much as God's praise, for them God prepared forgiveness and great reward (Al-Qur'an, 33:35).

These verses explain that woman has not been considered inferior by God. She like her male counterpart has been directed by God to seek his guidance. The Qur'an message is universal and open to everyone. Woman's function in the society is the same as that of a man. Islam admits the rights of women. Islam does not impose restrictions or restrains to the freedom and privileges of women. Prophet Muhammad (Peace be Upon Him) ordered the last sermon

Treat your women well and be kind to them for they are your partners and committed helpers (Khan, 2008).

A woman is equally important as compared to man as a member of society. In front of God, there are same standards of punishment and rewards for men and women, both came from the same essence and soul and they are equal. Neither gender can be superior because it would be a contradiction of equality. Men and women are regarded as equal, keeping in view their different nature and particular disposition. Islam gives the right to work, to earn money if women need it or want it. According to the Qur'an:

Men have a share of what they earn and women have a share of what they earn (Al-Qur'an, 4:32). 
Similarly, women enjoy having rights to property in Islam.

Men have share of what their parents and relatives leave behind and women have a share of what their parents and relatives leave behind, whether the estate be a small or large a legal share (Al-Qur'an, 4:7).

The verses from the Holy Qur'an clearly show how Islam determines the status of woman in society. The problem starts when people misinterpret the teachings of Islam, according to their own wishes. Scholars, throughout the history of Islam, male historians and religious scholars wrote about the teachings of Islam and they kept their gender biased approach in their work. Similarly different cultural and traditional practices have been incorporated in the teaching of Islam, which have spoiled the true teaching of Islam. A society that denies women their due rights and behaves them in undignified and blameworthy manner can be of a traditional tribal structure, but cannot be viewed as Islamic.

\section{Violence against Women in Pakistan}

The constitution of Pakistan give equal rights to man and woman as it says "there shall be no discrimination on the basis of sex alone. No citizen, otherwise qualifies for appointment in the service of Pakistan shall be discriminated against in respect of any such appointment on the ground only of ... sex, steps shall be taken to full participation of women in all spheres of national life. The state shall protect the marriage, the family, the mother. The state shall (ensure) that women are not employed in vacations unsuited to their sex".

In the year 2014, statistics shows that incidents of violence and injustices against women, because of natural disasters such as floods and ongoing war against terror in the tribal regions resulted in their displacement, making their plight worse. The year witnessed cases of extreme public brutality against women such as family bludgeoning a pregnant woman to death outside the High Court in Lahore for marrying without their approval (HRCP, 2014).

That the right to public space for women was fraught regarding security was also understand by two incidents in Baluchistan. In the first one, a masked man entered a jewellery shop in Quetta and sprayed acid on four women patrons. In the second incident, two teenage sisters shopping in Bazaar in Mastung were attacked in the same method in the province in 2012 in Dalbandin Kalat and Quetta, leaving out a terrible message that women venturing independently into the public domain would be attacked (HRCP, 2014). 
Each year promises are made for the protection of the women but to remain unfulfilled by the end of the year. Violence in Pakistan takes many forms varying from physical to mental torture many of which are not even recognized as violence by the victims. According to the Human Rights Commission of Pakistan, in 2014 "597 women and girls were gang raped, 828 raped, and 36 stripped in public in the country (HRCP, 2014).

\section{Cultural and Structural Violence}

Violence against women is a worldwide problem, it includes half of the humanity. Women all over the world face multiple forms of violence just because of being women. There are many cultural and structural causes which provide sound basis for the continual perpetuation of violence against women all over the world. Pakistani society is a true example of manifesting this violence where there are deep seated beliefs based on culture and traditions, norms and social institutions that legitimize and therefore perpetuate violence against women. Women are considered as personal properties of men and men control every aspect of lives of women including their behaviour and movements. Men have the rights to make decisions, and women have to follow their decisions in family, tribe, community and society in many areas, like in North West Frontier Province, Baluchistan, rural Sindh and rural Punjab, women are not even considered women come to be discussed in law in the same terms as material objects and possessions. This is normally reflected in Pakistan's rape laws, which treat the offence as one of theft of a male's private property, with no consideration for the woman's rights human beings. Rather, they are viewed as personal property with which to barter and trade. For instance, in rural areas, where traditions of women living in rural areas of Baluchistan where most of women have to bear the double burden of domestic and work outside the home mainly in fields. Many men in these rural areas completely consider women as subordinates, mere servants doing work in the home. Normally, a father in rural areas of Pakistan thinks that there is no benefit to give education to a daughter, because she will be to wash dishes after marriage. Men strongly believe that the actual duty of women is to work inside the home not outside.

In Pakistani society, working women are not liked or respected by most people and many men prefer not to marry them. Women are normally considered subordinates to men, because of economic interdependence. In short, working women are not considered good character human beings; because, to some extent, women have to become free from the dependence of men and they have become able to make decisions for themselves. It is normal in Pakistan for a husband to beat his wife, for a brother to beat his sister, and for father to beat his daughter, because of very minor issues, such as coming home late after the college, cooking poorly, or going out without permission. Unfortunately, it is the traditional setup of Pakistani society, whereby a man is expected to be responsible person for the nourishment of the family, in economic terms. Due to this cultural belief, men try 
for jobs, and women, who are dependent on men, try to marry that man who has a nice job and economic stability. This is also an important reason for the backwardness of Pakistani economy, where half of the population does not work and remains dependent on the working half of the population. In Pakistan women have strict limitations regarding their thinking and movements. When she wears any dress, she will keep the perceptions of her close male relatives such as brother, husbands and fathers in view. Excluding some educated and urbanized families, almost every woman in Pakistan goes outside the home with the permission of man. She will get education according to the dictations and decisions of her male family members. She cannot marry without the consent of her male family members Pakistani society is a society where a man is the head of family with complete decision making powers, and the woman normally obeys the orders of the man, because the man is giving her basic necessities of life such as food, shelter and clothes (HRCP, 2014).

Because of deep seated cultural and traditional practices and inadequate responses of society and government, in Pakistan women are the victims of direct violence and in most cases, they are killed mercilessly in the name of honour, customs and compensation of crimes or bringing insufficient dowry. It can be said that when a husband kills his female relative because of suspicion or any other reason. When the majority of man follow the same practice of killing women, it is structural violence, which is embedded in patriarchal setup of society and when society does not give adequate attention towards this in human behaviour, it can be said to be a manifestation of cultural violence. It is unfortunate that Pakistani society is not acting against this vicious circle of violence to a considerable extent because of ignorance and an overall gender biased approach. Violence against women in Pakistan does not only bring physical injuries to women but also has psychological impacts on their thinking. Domestic violence leaves a deep seated trauma with no proper healing. Further it brings misery, especially in cases of rape, when the victims of rape has to provide four male witnesses in order to prove rape. Society consider women as responsible for adultery and in some cases, women are killed by their relatives because she has brought shame towards the family. This is called honour killing.

Honour killing is one of the worst forms of violence against women. It is an extreme form of direct physical violence, which is marked by great suffering. In recent years, Pakistan has been criticized because of the dramatic rise in the incidence of honour killings in the country.

Honour killings can also be described as extra judicial punishment of a female relative for assumed sexual and marriage offences. These offences, which are considered as a misdeed or insult, include sexual faithlessness, marrying without the will of parents or having a relationship that the family considers to be inappropriate and rebelling against the tribal and social matrimonial customs. These acts of killing women are justified on 
the basis that the offence has brought dishonour and shame to family or tribe (HRCP, 2014).

Honour killings are justified in the name of religious tradition. These traditions have become blurred and corrupted, allowing for widespread abuse. Women and young girls are being killed by husbands, fathers, and brothers who feel shame as been brought upon their family. Authorities blame women for their deaths, believing that they deserve punishment for their actions and murder is a justifiable action taken by men. Hundreds of women die each year in Pakistan as a result of Honour Killings. Many killings go unreported, placing some estimates of those actually dying in the thousands one in every five homicides in Pakistan are related to an honour killing.

\section{Women's Human Rights and Islam}

Pakistani people claim their society as an Islamic society. Islam admits the rights of women. Islam does not impose restrictions or restrains to the freedom and privileges of women. The rights of women are present vividly and resolutely in the teachings of Islam. A woman is equally important to man as member of society. In front of God, there are same standards of punishments and rewards for women and men. Since men and women both came from the same essence, they are equal in their humanity.

The discussion in the beginning of the paper and verses of Holy Quran clearly show how Islam determines the status of women in society. The problem arises when people misinterpret the teachings of Islam according to their own wishes. Scholars, such as highlighted throughout the history of Islam, male historians and religious scholars wrote about the teachings of Islam and they kept their gender biased approach in their work. Similarly, different cultural and traditional practices have been incorporated in the teachings of Islam, which have spoiled the true teachings of Islam.

After analyzing the rights given by Islam, it will be difficult to consider Pakistani society as an Islamic society where traditional and social norms put strict obstacles in the way of progress for women. A society that denies women their due rights, and behaves towards them in an undignified and blameworthy manner can be an example of a traditional tribal structure, but cannot be viewed as Islam.

\section{Conclusions}

Violence against women is a concern of noticeably significant importance at societal and family levels. Domestic or intra family violence perpetrated by both male and female family members and relatives deserves special attention. Domestic violence is a serious threat to basic human rights and psychological well being. Violence against women is a 
complex problem which requires coordinated solutions, involving the participation of both the state and civil society. There is a strong and urgent need for mobilizing and adequately utilizing all allied sectors of society for formulating policy and programs. These involve the development of community networks in order to provide case and support to people who are victims of violence. This also involve the promotion of non violent relations in public and private lives of men and women (Shamsuddin, 2007). Regressive social practices, entrenched deeply in tribal and feudal customs and traditions, coupled with an obscurantist interpretation of religious leaders, are the main hurdles in the way of women, demanding their rights. Changing social attitudes towards women in Pakistani society requires sustained efforts. Pakistan cannot become a moderate, progressive and a prosperous Muslim country without strengthening civil society. This requires first and foremost giving men and women equal access to opportunities in life, with particular emphasis on the protection of the rights, safety and well being of women. If half of the population of Pakistan is spending life marked by strong feelings of fear and insecurity, directly or indirectly, how can Pakistan stand among the prosperous countries of the world? How Pakistan, which was created on the name of Islam, can be a role model for Islamic countries as well. Only through the education of women and by making them leaders and equal participants in decision making and in deciding their own future, that Pakistan will ever be free itself from the bonds of illiteracy, inequality and poverty. International declarations and agreements may play an important role to pressurize the government of Pakistan to make adequate laws or policies in order to control the violence against women but the ultimate solution lies in the realization of gender equality. Change can come and must come from both men and women. To work for a society free from gender based violence is not be possible if Pakistani people do not take into account or address the role of women. Women not only are mothers, daughters sisters and wives but they are human beings as well. They should not be treated as objects whose existence is defined by their relationship to men. Rather, they should be treated as equals having the right to live, work, contribute, earn. Everyone should acknowledge this role or right in Pakistani society from government to a common man.

The reality is this that women are as capable as men in any task not involving excessive physical activity. Unless the men of Pakistan do not react against the patriarchal patterns of society, social conditions will remain problematic and further promoting violence against women. Gender inequality is a product of the society's patriarchal and pathetic attitude and has nothing to do with the knowing or thinking powers of women. Violence against women sustains its momentum. Handling one factor will obviously effect other factors. The government has to address concerning issues of human rights. Pakistan will remain to be a country in which women will be living like second class citizens. It is not bad to be backward in material progress but it is bad to be backward in thoughts. At least people of Pakistan should not be mentally backward and narrow minded. If people of Pakistan try to remove this social illness, things, may start to change. 
In the end I would conclude that Islam may tolerate many things but it teaches zero tolerance for injustice, oppression and violation of rights of human beings. In Surah e Nisa Allah says:

And what is wrong with you that you fight not in the Cause of Allah, and for those weak, ill-treated and oppressed among men, women, and children, whose cry is: "Our Lord! Rescue us from this town whose people are oppressors; and raise for us from You one who will protect, and raise for us from You one who will help" (Al-Quran, 4:75).

This verse signifies the status of women in society.

\section{References}

Al-Qur'an, 16:58-59

Al-Qur'an, 16:72

Al-Qur'an, 17:32

Al-Qur'an, 30:21

Al-Qur'an, 31:14

Al-Qur'an, 33:35

Al-Qur'an, 4:19

Al-Qur'an, 4:32

Al-Qur'an, 4:58

Al-Qur'an, 4:7

Al-Qur'an, 49:13

Al-Qur'an, 7:189

Al-Qur'an, 9:71 
Al-Quran, 4:75

Alston, P. (1992). The United Nations and Human Rights: A Critical Appraisal. Oxford England: Clarendon Press, p.474.

Blattberg, C. (2009). Patriotic Elaborations: Essays in Practical Philosophy. Montreal Que.: McGill-Queen's University Press, pp.43-48.

Blattberg, C. (2010). The Ironic Tragedy of Human Rights, Patriotic Elaborations: Essays in Practical Philosophy. USA: McGill Queen's University Press, pp 43-49.

Brownie, C. (2003). Principal of Public International Law; Oxford University Press, p.532.

Donnley, J. (1989). Universal Human Rights in Theory and Practice; New York: Cornel University, p.147.

Hannum, H., Anaya, S. J. \& Shelton, D. (2011). International Human Rights: Problems of Law, Policy, and Practice. Austin: Wolters Kluwer Law \& Business.

Henkin, Louis. (1987). The International Bill of Right: The Universal Declaration and the Covenants, International Enforcement of Human Rights, Jolowicz: p.9.

HRCP. (2015). State of Human Rights in 2014; Lahore, pp.201-202

Johnson, M. G., Symonides, J., UNESCO. \& United Nations. (1998). The Universal Declaration of Human Rights: A History of its Creation and Implementation, 1948-1998. Paris: UNESCO Pub.

Khan, M. M. (2008). Muslim 100: The Lives, Thoughts and Achievements of the Most Influential Muslims in History. Leicester: Kube.

Littman, David G. (2003). Human Rights and Human Wrongs, National Review, New York, http://www.nationalreview.com/article/205577/human-rights-and-humanwrongs-david-g-littman

Malcolm, Shah (2008). International Law (6 $6^{\text {th }}$ ed.) Leiden Cambridge University Press, p.277.

Olivia Ball, Paul, Greedy. (2006). The Non Nonsense Guide to Human Rights, New Internationalist, Oxford: Oxford University Press, pp.37-38. 
Safdar, Mahmood. (2005-6). International Affairs, Lahore: Jenny Publication, pp.20-23.

Sani, Hafiz Muhammad Dr. (1999). Mohsin-e-Insaniat aur Insani Haqooq, Karachi, Darul Ishaat, pp.137-147

Shamsuddin, Muhammad (2007). Culturation through Mass Communication: Psychological and Interpersonal Consequences, Pakistan Journal of Clinical Psychology, Institute of Clinical Psychology, University of Karachi, pp.33-50.

The Constitution of Pakistan, Article 25, 27, 35, http://www.pakistani.org/pakistan/ constitution/

United Nations Charter Article 1 (3) https://treaties.un.org/doc/Publication/CTC/ uncharter.pdf

Dr. Abida Parveen is an Associate Professor in the Sheikh Zayed Islamic Centre, University of Karachi. 